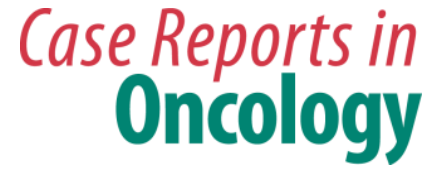

Case Rep Oncol 2019;12:650-656

DOI: 10.1159/000502053

Published online: August 13, 2019

2019 The Author(s)

Published by S. Karger AG, Basel

www.karger.com/cro

This article is licensed under the Creative Commons Attribution-NonCommercial 4.0 International License (CC BY-NC) (http://www.karger.com/Services/OpenAccessLicense). Usage and distribution for commercial purposes requires written permission.

\title{
Lung Adenocarcinoma with Cheek Dysesthesia as an Initial Symptom: A Case Report and Literature Review
}

\author{
Nobuyuki Bandoh $^{a}$ Haruyuki Ichikawa ${ }^{a, d}$ Atsuyoshi Asahi ${ }^{b}$ \\ Michihisa Kono ${ }^{a, d}$ Shohei Harabuchi ${ }^{d}$ Ryosuke Sato ${ }^{a} \quad$ Akihiro Uemura $^{a}$ \\ Takashi Goto $^{a}$ Tomomi Yamaguchi $^{c}$ Yasutaka Kato ${ }^{c}$ \\ Hironori Furukawac Hidehiro Takei ${ }^{\mathrm{d}}$ Yasuaki Harabuchi $^{\mathrm{e}}$ \\ a Department of Otolaryngology-Head and Neck Surgery, Hokuto Hospital, Obihiro, Japan; \\ ${ }^{b}$ Department of General Medicine, Hokuto Hospital, Obihiro, Japan; 'Department of \\ Biology and Genetics, Laboratory of Cancer Medical Science, Hokuto Hospital, \\ Obihiro, Japan; dDepartment of Surgical Pathology, Asahikawa Medical University \\ Hospital, Asahikawa, Japan; eDepartment of Otolaryngology-Head and Neck Surgery, \\ Asahikawa Medical University, Asahikawa, Japan
}

\section{Keywords}

Lung adenocarcinoma - Sphenoid bone - Metastasis - Trigeminal nerve $\cdot$ Epidermal growth factor receptor (EGFR)

\begin{abstract}
Metastasis from lung carcinoma to the sphenoid bone is rare. Patients with symptoms related to sphenoid bone metastasis as the initial presentation of carcinoma are thus also rare. Herein, we report the case of a patient presenting with only cheek dysesthesia as the first sign of lung adenocarcinoma. The 74-year-old woman presented with a 2-month history of left cheek dysesthesia. CT showed a tumor around $2.5 \mathrm{~cm}$ in diameter with heterogeneous enhancement of the central focus at the left foramen rotundum in the sphenoid bone. We endoscopically biopsied the tumor through the left sphenoid sinus. Results of histologic examination were
\end{abstract}




\section{Case Reports in Oncology}

Case Rep Oncol 2019;12:650-656

DOI: $10.1159 / 000502053$

2019 The Author(s). Published by S. Karger AG, Basel www.karger.com/cro

Bandoh et al.: Lung Adenocarcinoma with Cheek Dysesthesia as an Initial Symptom: A Case Report and Literature Review

consistent with lung adenocarcinoma. FDG-PET/CT analysis demonstrated lung carcinoma that had already metastasized to mediastinal lymph nodes and multiple bones, such as the ribs and lumbar vertebras, in addition to the sphenoid bone. As EGFR gene mutation (p.L858R) was identified, the patient was treated with oral gefinitib. This treatment proved quite effective, and the patient remains alive without tumor growth as of 18 months.

(C) 2019 The Author(s)

Published by S. Karger AG, Basel

\section{Introduction}

Lung adenocarcinoma is most often detected in metastatic stage IV, and common sites of metastasis are the brain, liver, bones and adrenal glands [1]. Bone metastases from lung adenocarcinoma occur in about $40 \%$ of cases, but only around $3 \%$ of bone metastasis are found within the skull bones, including the sphenoid bone [2,3]. This butterfly-shaped bone in the middle of the skull base contains indispensable structures, such as the pituitary gland, optic chiasm, cavernous sinus, internal carotid artery, and cranial nerves II-VI. Metastasis of lung adenocarcinoma to the sphenoid bone is rare and few cases have been reported. We describe an unusual case with trigeminal neuropathy caused by sphenoid bone metastasis from lung adenocarcinoma as the initial symptom.

\section{Case Report}

A 74-year-old woman, a housewife and non-smoker, presented with a 2-month history of left cheek dysesthesia. She had not complained of any other symptoms such as cough, sputum, general fatigue or visual impairment. Computed tomography (CT) showed a mass around 2.5 $\mathrm{cm}$ in diameter with heterogeneous enhancement and bone destruction at the central focus on the left foramen rotundum in the sphenoid bone, extending from the left middle cranial and pterygopalatine fossa to the left orbital apex (Fig. 1a-c). Initially, diagnoses of trigeminal schwannoma, meningioma or sinonasal carcinoma were considered. We performed endoscopic sinus surgery under general anesthesia and resected a yellowish mass from the lateral wall of the left sphenoid sinus (Fig. 1d). Histopathologic examination revealed proliferation of atypical cells with large irregular nuclei (Fig. 2a). Immunohistologic analysis showed tumor cells with positive cytoplasmic staining for AE1/AE3 (Fig. 2b), CAM5.2 (Fig. 2c), CK7 (Fig. 2d) and TTF-1 (Fig. 2e). However, negative results were obtained for CK 20 (data not shown). The percentage of Ki-67-positive cells was approximately 30\% (Fig. 2f). Unexpectedly, these findings indicated a histology consistent with lung adenocarcinoma. We therefore conducted a general search for lesions, including the lungs. Chest CT revealed 4-cm mass with irregular margins in the right upper lung (Fig. 3a). Fluorodeoxyglucose (FDG)-positron emission tomography (PET)/CT revealed a mass with strong uptake in the right lung and ipsilateral upper mediastinum indicating lymph node metastases (Fig. 3b). Multiple bone metastases were identified in the left $3 \mathrm{rd}$ rib and 1st and 5th lumbar vertebras. In laboratory examinations, serum calcium was $9.1 \mathrm{mg} / \mathrm{dl}$ (normal: $8.6-10.2 \mathrm{mg} / \mathrm{dL}$ ), alkaline phosphatase (ALP) was 769 U/L (normal: 104-338 U/L), carcinoembryonic antigen (CEA) was $32.2 \mathrm{ng} / \mathrm{mL}$ (normal: <5 


\section{Case Reports in Oncology}

Case Rep Oncol 2019;12:650-656

DOI: $10.1159 / 000502053$

C 2019 The Author(s). Published by S. Karger AG, Basel www.karger.com/cro

Bandoh et al.: Lung Adenocarcinoma with Cheek Dysesthesia as an Initial Symptom: A Case Report and Literature Review

$\mathrm{ng} / \mathrm{mL}$ ). Genetic analysis revealed only a missense mutation in the epidermal growth factor receptor (EGFR) gene (p.L858R) in exon 21. No deletions in exon 19 or 20 of the EGFR gene were not identified. KRAS and NRAS mutations were also not identified. The final clinical staging was cT2N1M1c and stage IVB, EGFR-mutant lung adenocarcinoma. Oral administration of gefinitib at $250 \mathrm{mg}$ every day proved quite effective. Although cheek dysesthesia remained unrelieved, the patient remains alive without any evident growth of the tumors in the lung or sphenoid bone as of 18 months.

\section{Discussion}

Metastasis to the sphenoid bone has been reported from lung, breast, prostate, pancreas and thyroid carcinomas [4]. The mechanism underlying metastasis from lung adenocarcinoma to the sphenoid bone is mainly considered to involve hematogenous spread of tumor cells to the bone. In the present case, we suspected that circulating tumor cells might have become trapped in either the cavernous sinus, or vessels accompanying the trigeminal nerve or meninges around the foramen rotundum. The metastatic tumor might have compressed the second branch of the trigeminal nerve, resulting in trigeminal neuropathy and subsequent cheek dysesthesia.

Characteristics of 12 patients with metastasis of lung carcinoma to the sphenoid bone identified from the literature published since 1990 are summarized in the Table 1 [4-11]. Median age of the patients was 63 years (range, 47-76 years). The majority of patients were female ( 9 females, 3 males). A history of smoking was reported in 4 patients. Adenocarcinoma was the most common histological type, seen in 6 cases (50\%).

Metastasis to the sphenoid bone may cause a variety of symptoms, including visual symptoms such as diplopia, ptosis, changes in visual acuity, retro-orbital or frontal headache, and facial dysesthesia. These symptoms naturally varied depending on location, size, and cranial nerves affected by the tumor. The most frequent clinical symptom was headache or pain, appearing in 7 cases (58\%), followed by ophthalmological symptoms in 6 cases (50\%) and facial symptoms including dysesthesia or pain associated with trigeminal nerve in 5 cases (41\%) (Table 1). Eight (75\%) of the 12 patients showed symptoms relating to sphenoid bone metastasis as an initial presentation of the lung carcinoma. Only one report described trigeminal neuropathy caused by metastasis to Meckel's cave, site of the ganglion of the trigeminal nerve, resulting in the symptoms seen as the first presentation of lung adenocarcinoma [8]. The reason our patient did not complain of any respiratory symptoms, back pain, or general symptom remains unclear. Primary lung carcinoma would usually be expected to have been discovered at a medical examination before the patient became aware of any symptoms such cheek dysesthesia.

In the present case, we were able to obtain biopsy specimens through the sphenoid sinus and suspected metastasis of lung adenocarcinoma. Immunohistologic analysis plays an important role in confirmating the origin of a carcinoma. A previous study demonstrated that $73 \%$ of primary lung adenocarcinomas expressed TTF-1, whereas all non-pulmonary adenocarcinomas lacked TTF-1 staining [12]. CK7 expression is significantly more frequent in adenocarcinomas of lung and breast origin than in those of gastrointestinal origin. In contrast, CK20 expression is significantly more prevalent in adenocarcinomas of gastrointestinal origin 
than in those of lung or breast origin. The combination of TTF-1+CK7+CK20- is thus strongly associated with lung adenocarcinoma.

Several treatments have been described in the literature, including radiotherapy and/or chemotherapy with CDDP and gemcitabine. Many recent reports have suggested the effectiveness of EGFR-tyrosine kinase inhibitors (TKIs) in treating lung carcinoma [13]. Gefitinib, a molecularly targeted EGFR-TKI, is reported to have a considerable efficacy in female patients and nonsmokers, especially those with adenocarcinoma [2]. Gefitinib has shown rapid and improved response rate in patients with lung adenocarcinoma with bone metastasis showing EGFR-activating mutations [2].

The prognosis of cases with metastasis to the sphenoid bone from lung carcinoma is quite poor. Seven (58\%) of the 12 patients reported were dead within 5 months (Table 1). Life expectancy after skull metastasis is estimated to be around 5 months [14]. However, treatment with an EGFR-TKI may improve survival after bone metastasis [2]. In the present case with EGFR mutation, administration of EGFR-TKI proved quite effective and our patient remain alive with stable disease. However, in the near future, if pain develops in the face, chest or back, radiotherapy or another drug will be needed.

In conclusion, both physicians and neurologists must be aware of the possibility of trigeminal neuropathy resulting from metastases. Most notably, metastases may be the initial presenting sign of a primary tumor, as in the patient reported here. Adenocarcinoma is the most common histologic subtype of lung carcinoma with metastasis to the skull bone. When encountering tumors in the head and neck region, histological examination and thorough clinical and laboratory investigations should be performed for other primary malignancies, particularly the lung.

\section{Acknowledgments}

We would like to thank FORTE Scientific Communications (www.forte-science.co.jp) for editing a draft of this manuscript.

\section{Statement of Ethics}

This material has not been published in whole or in part elsewhere. All authors have been personally and actively involved in substantive work leading to the manuscript and will hold themselves jointly and individually responsible for its content. All procedures performed on patient tumor samples in this study were conducted in accordance with the ethical standards of the Institute Ethics Committee and the 1964 Declaration of Helsinki and its later amendments or comparable ethical standards. Written informed consent for publication of clinical details and images was obtained from the patient and her family. 


\section{Disclosure Statement}

The authors declare that no financial or other conflict of interest exists in relation to the content of this paper.

\section{Author Contributions}

NB, MK and SH performed biopsy. IH performed literature search. AA provided treatment with chemotherapy. RS, AU and TG performed bedside care. TY performed mutational analyses. HT performed pathologic investigations. HF and YH conceived the study design. NB drafted the manuscript. All authors approved the final version of the manuscript.

\section{References}

1 Popper HH. Progression and metastasis of lung cancer. Cancer Metastasis Rev. 2016 Mar;35(1):75-91.

2 Sugiura H, Yamada K, Sugiura T, Hida T, Mitsudomi T. Predictors of survival in patients with bone metastasis of lung cancer. Clin Orthop Relat Res. 2008 Mar;466(3):729-36.

3 Turner RC, Lucke-Wold BP, Hwang R, Underwood BD. Lung cancer metastasis presenting as a solitary skull mass. J Surg Case Rep. 2016 Jun;2016(6):rjw116.

4 Mickel RA, Zimmerman MC. The sphenoid sinus—a site for metastasis. Otolaryngol Head Neck Surg. 1990 Jun;102(6):709-16.

5 Weilbaecher C, Patwardhan RV, Fowler M, Willis BK, Nanda A. Metastatic lesions involving the sella: report of three cases and review of the literature. Neurol India. 2004 Sep;52(3):365-8.

6 Huang CT, Hong RL. Nasion swelling as the presenting symptom of lung adenocarcinoma. J Thorac Oncol. 2009 Apr;4(4):555-8.

7 Gupta PK, Mital M, Dwivedi A, Gupta K. Metastasis of greater wing of sphenoid bone in bronchogenic carcinoma: a unusual case report. J Cancer Res Ther. 2011 Apr-Jun;7(2):195-7.

8 Cerase A, Brindisi L, Lazzeretti L, Pepponi E, Venturi C. Lung cancer presenting with trigeminal neuropathy. Neurol Sci. 2011 Oct;32(5):927-31.

9 Zelenak M, Doval M, Gorscak JJ, Cuscela DO. Acute cavernous sinus syndrome from metastasis of lung cancer to sphenoid bone. Case Rep Oncol. 2012 Jan;5(1):35-42.

10 Priddy B, Hardesty DA, Beer-Furlan A, Otto B, Prevedello DM. Cerebrospinal Fluid Leak Rhinorrhea after Systemic Erlotinib Chemotherapy for Metastatic Lung Cancer: A Familiar Problem from an Unfamiliar Culprit. World Neurosurg 2017;108:992 e11-4. https://doi.org/10.1016/j.wneu.2017.08.183.

11 Fukai S, Okabe N, Mine H, Takagi H, Suzuki H. Garcin syndrome caused by sphenoid bone metastasis of lung cancer: a case study. World J Surg Oncol. 2018 Mar;16(1):46.

12 Lin HY, Chiang CP, Wang YP, Yu-Fong Chang J. Metastatic lung carcinoma in the right maxilla. J Formos Med Assoc. 2018 Dec;117(12):1130-2.

13 Mitsudomi T, Kosaka T, Endoh H, Horio Y, Hida T, Mori S, et al. Mutations of the epidermal growth factor receptor gene predict prolonged survival after gefitinib treatment in patients with non-small-cell lung cancer with postoperative recurrence. J Clin Oncol. 2005 Apr;23(11):2513-20.

14 Mitsuya K, Nakasu Y, Horiguchi S, Harada H, Nishimura T, Yuen S, et al. Metastatic skull tumors: MRI features and a new conventional classification. J Neurooncol. 2011 Aug;104(1):239-45. 


\section{Case Reports in Oncology}
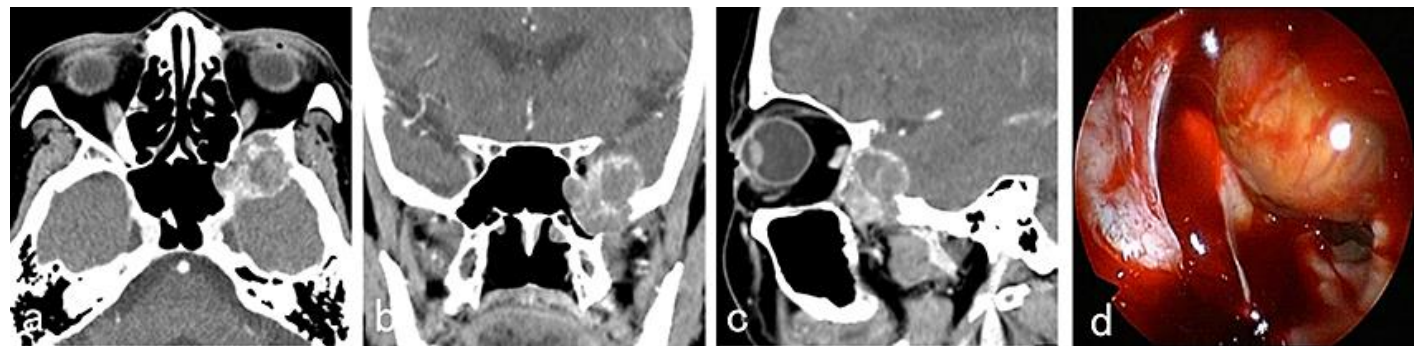

Fig. 1. Computed tomography (CT) shows a mass of around $2.5 \mathrm{~cm}$ in maximal diameter with heterogeneous enhancement and bone destruction at the central focus on the left foramen rotundum, extending from the left middle cranial and pterygopalatine fossa to the left orbital apex (a-c). A yellowish tumor is observed on the lateral side of the left sphenoid sinus (d).
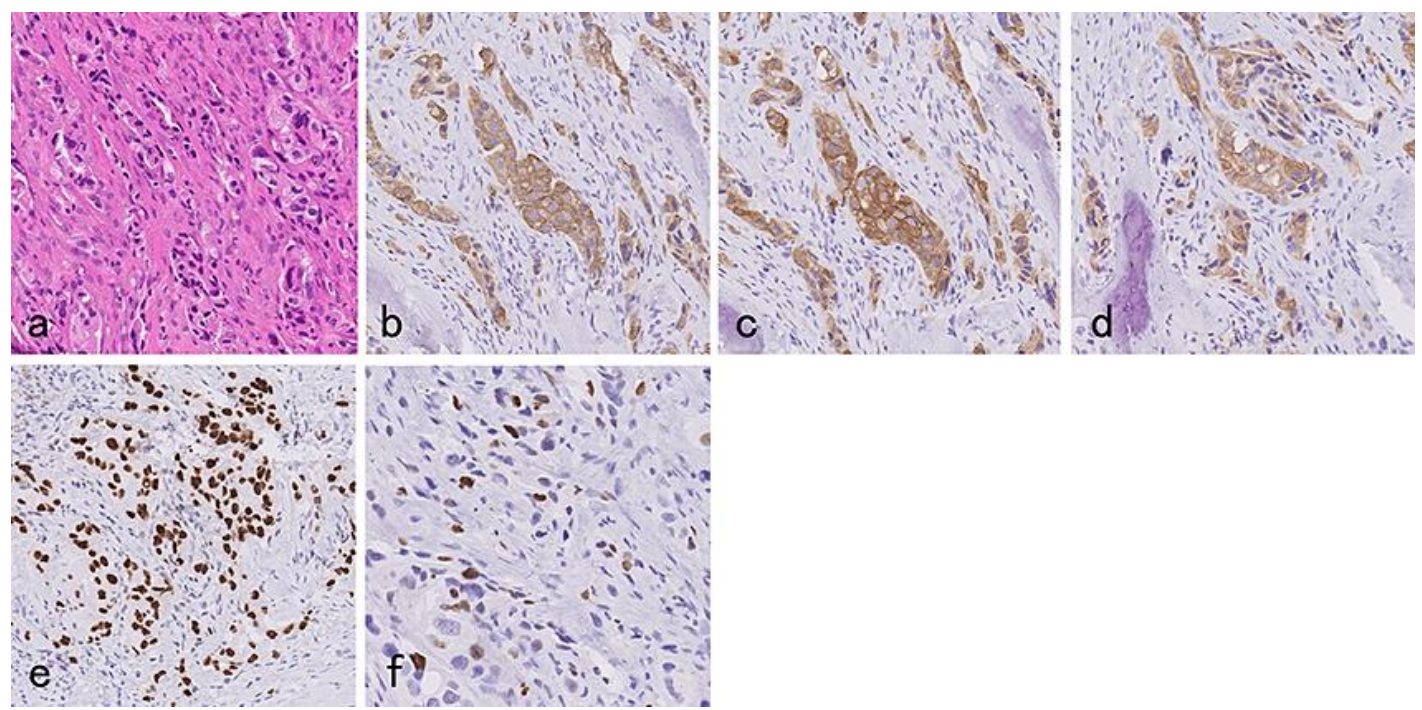

Fig. 2. Histopathologic examination with hematoxylin and eosin staining reveals a proliferation of atypical cells with large irregular nuclei (a). Immunohistologic analysis shows tumor cells with membrane staining for AE1/AE3 (b), CAM5.2 (c), CK7 (d) and TTF-1 (e). The percentage of Ki-67-positive cells is approximately $30 \%$ (f). Magnification $\times 400$. 

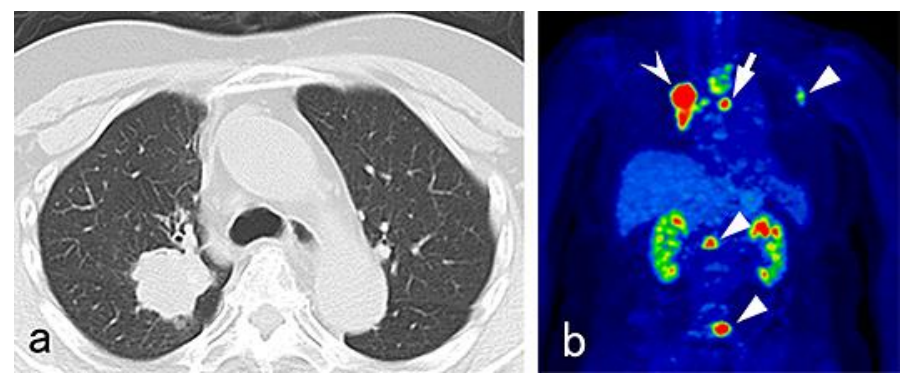

Fig. 3. CT reveals a 4-cm mass with irregular margins in the right upper lung (a). FDG-PET/CT shows strong uptake in not only the primary lung tumor (arrowhead), but also metastatic lymph nodes in the right upper mediastinum (white arrow), left third rib, and 1st and 5 th lumbar vertebras (triangles) (b).

Table 1. Reported cases with metastasis to shenoid bone from lung carcinoma

\begin{tabular}{|c|c|c|c|c|c|c|c|}
\hline Author & $\begin{array}{l}\text { Age/ } \\
\text { Gender }\end{array}$ & $\begin{array}{l}\text { Smoking } \\
\text { history }\end{array}$ & Histology & $\begin{array}{l}\text { Symptoms relating } \\
\text { to sphenoid sinus }\end{array}$ & $\begin{array}{l}\text { Cranial } \\
\text { nerve } \\
\text { involvement }\end{array}$ & Treatment & $\begin{array}{l}\text { Prog- } \\
\text { nosis }\end{array}$ \\
\hline \multirow[t]{3}{*}{$\begin{array}{l}\text { Mickel [4], } \\
1990\end{array}$} & $51 / F$ & NR & Bronchogenic ca. & $\begin{array}{l}\text { Ophthalmoplegia, } \\
\text { ptosis }\end{array}$ & II, III, IV, VI & RT, CT & $\begin{array}{l}\text { Dead } \\
(1 \mathrm{wk})\end{array}$ \\
\hline & $71 / F$ & NR & Poorly diff. ca. & $\begin{array}{l}\text { *Headache, diplopia, } \\
\text { decreased visual acuity }\end{array}$ & II, V, VI & NR & $\begin{array}{l}\text { Dead } \\
(5 \mathrm{mo})\end{array}$ \\
\hline & $47 / \mathrm{M}$ & NR & Adenocarcinoma & *Headache, facial pain & III, IV, VI & $\begin{array}{l}\text { CDDP, mitomycin-C, } \\
\text { vinblastine }\end{array}$ & $\begin{array}{l}\text { Dead } \\
(1 \mathrm{mo})\end{array}$ \\
\hline \multirow[t]{2}{*}{$\begin{array}{l}\text { Weilbaecher } \\
{[5], 2004}\end{array}$} & $52 / F$ & + & Small cell ca. & $\begin{array}{l}\text { *Hemiplasia, ptosis, } \\
\text { medial deviation }\end{array}$ & III & Gamma knife & $\begin{array}{l}\text { Alive } \\
(1 \mathrm{mo})\end{array}$ \\
\hline & $67 / F$ & + & Small cell ca. & *Headache, diplopia & VI & CT & Dead \\
\hline $\begin{array}{l}\text { Huang [6], } \\
2009\end{array}$ & $59 / F$ & - & Adenocarcinoma & $\begin{array}{l}\text { *Nasion swelling, } \\
\text { nasal stuffness, facial } \\
\text { numbness }\end{array}$ & $\mathrm{V} 2$ & $\begin{array}{l}\text { CDDP, } \\
\text { Gemcitabine }\end{array}$ & Alive \\
\hline $\begin{array}{l}\text { Gupta [7], } \\
2011\end{array}$ & $60 / \mathrm{M}$ & NR & Adenocarcinoma & $\begin{array}{l}\text { *Pain and swelling of } \\
\text { eye, diplopia }\end{array}$ & & NR & NR \\
\hline $\begin{array}{l}\text { Cerase [8], } \\
2011\end{array}$ & $69 / \mathrm{M}$ & + & Adenocarcinoma & ${ }^{*}$ Cheek paresthesia & $\mathrm{V} 2$ & RT & $\begin{array}{l}\text { Dead } \\
(2 \mathrm{wks})\end{array}$ \\
\hline $\begin{array}{l}\text { Zelenak [9], } \\
2012\end{array}$ & $59 / F$ & NR & Squamous cell ca. & $\begin{array}{l}\text { Headache, hearing } \\
\text { loss, facial pain }\end{array}$ & III-VIII & RT, CDDP, taxol & Dead \\
\hline $\begin{array}{l}\text { Priddy [10], } \\
2017\end{array}$ & $66 / F$ & + & Adenocarcinoma & $\begin{array}{l}\text { Headache, fever, CSF } \\
\text { rhinorrhea }\end{array}$ & & Erlotinib & $\begin{array}{l}\text { Alive } \\
(2 \mathrm{mo})\end{array}$ \\
\hline $\begin{array}{l}\text { Fukai [11], } \\
2018\end{array}$ & $76 / F$ & - & NSCLC & Headache, diplopia & IV, V1, VI & RT & $\begin{array}{l}\text { Dead } \\
(5 \mathrm{mo})\end{array}$ \\
\hline Present case & $74 / F$ & - & Adenocarcinoma & ${ }^{*}$ Cheek dysesthesia & $\mathrm{V} 2$ & Gefinitib & $\begin{array}{l}\text { Alive } \\
(18 \mathrm{mo})\end{array}$ \\
\hline
\end{tabular}

NR, not reported; CT, chemotherapy; RT, radiotherapy; CDDP, cisplatin; NSCLC, non small cell lung carcinoma; CSF, cerebrospinal fluid. * Initial symptom for lung carcinoma prior to respiratory symptoms. 